Article

\title{
Exploring Public-Private Partnership Scheme in Operation and Maintenance Stage of Railway Project
}

\author{
Herawati Zetha Rahman, Perdana Miraj *(1) and Azaria Andreas \\ Department of Civil Engineering, Faculty of Engineering, Pancasila University, DKI Jakarta 12640, Indonesia; \\ zetha.hera@univpancasila.ac.id (H.Z.R.); azaria.andrea@univpancasila.ac.id (A.A.) \\ * Correspondence: perdanamiraj@univpancasila.ac.id
}

Received: 20 October 2019; Accepted: 4 November 2019; Published: 19 November 2019

\begin{abstract}
Public-private partnership (PPP) has been extensively used in many sectors worldwide to provide alternative funding for public infrastructure. However, limited evidence found that this scheme was successfully adopted in railway transport particularly in the later stage of the project life cycle. Private participation during operation and maintenance stages are worthy of comprehensive research to cope with recovery of public investment and institutionalization problems. This research aims to analyze the potential of unbundling scenarios based on railway components by taking into account the Light Rail Transit (LRT) project in developing countries as the case study. A life cycle cost evaluation and sensitivity analysis were used to formulate a practical and regulatory framework for the macro-level of decision-making modeling. The findings indicate a possible scenario by considering the passenger demand, ticket price, and government support to generate the best option based on net present value (NPV) and internal rate of return (IRR). The proposed alternative recommends an attractive investment return for private interest, encourages lower support for government subsidy, and offers a reasonable tariff for the users. The study also suggests future implications from the adoption of research findings which may affect policy formulation and railway industry as a whole.
\end{abstract}

Keywords: developing countries; life cycle cost; light rail; transportation

\section{Introduction}

Public-private partnership (PPP) has been used by various countries worldwide as one of the tools to cope with the lack of funding by the government in providing public infrastructure. Western and central European countries use this type of partnership to gain project advantages through a division of responsibility between the public and private sectors [1,2]. Private participation was also adopted in other parts of the world such as the United States and eastern countries in Asia to mitigate risks that occurred in the project development and share equal responsibility in terms of project finance and resources in the longer-term $[3,4]$.

Southeast Asian countries such as Malaysia, Singapore, Thailand, Vietnam, Philippines, and Indonesia also adopt the concept of PPP in the past decade mainly to expand state capability in providing physical assets for the public, and to reduce monopoly in the market. This scheme offers a prospective scenario for the public agency by providing maximum value for money in the project through life cycle cost optimization and market competition. PPP encourages the government to focus on services for public interest and supporting policy and regulation, rather than dealing with asset procurement and project operation [5]. On the other hand, the private sector also gained benefits from this scheme to maximize assets for income generation and extend the expertise for international bidding.

PPP in Southeast Asian countries is still limited. The Philippines successfully awarded 16 PPP contracts worth $\$ 6.4$ billion since 2010 including airports, toll roads, education buildings, and water supply. In Thailand, there are 44 PPP projects ranging from transportation and logistics, utilities, 
telecommunication, and property development [6]. On the other hand, the government of Indonesia claimed 57 projects have used PPP schemes which consists of 36 connectivity projects, 11 urban facilities, and 10 social projects development [7]. Most of the projects are part of the Strategic National Project from highways, energy, telecommunication, water, airports, wastewater treatment, and hospitals. Until 2017 , two projects are currently in the operation stage, which require US\$159.1 million of investment, 11 projects (US\$ 8757 billion) in the construction stage, 11 projects (US\$ 4.4 billion) in the transaction stage, 18 projects (US $\$ 3338$ billion) in the preparation stage, and 8 projects in the planning stage.

Based on previous results, Indonesia experiences a slow adoption of PPP due to various reasons. The Indonesia Infrastructure Guarantee Fund (IIGF), as the public agency responsible for guarantee PPP project in Indonesia, argued that lack of commitment from the In-Charge of Partnership Project (PJPK) and limited knowledge in conducting PPP schemes in a structured manner are the two biggest obstacles for PPP adoption in the country [8]. Furthermore, PPP implementation in Indonesia experienced a lack of emphasis on the value for money (VfM) concept during feasibility studies. PPP is often perceived as an instrument to gain funding for infrastructure, not as a way to offer optimum value for projects from a private point of view and collaboration in the longer term.

PPP in railways is less than successful for implementation, not only in developing countries but also in developed ones. Channel Tunnel and London Underground, both in the UK and Taiwan High-Speed Railways, are some projects experiencing a challenge to integrate PPP schemes particularly related to financial return [9]. The government of Indonesia also encourages the use of PPP to the railway sector but none of them have been implemented yet. This paper will present an analysis of the possibilities in adopting the PPP scheme in railway project development by taking into account the Greater Jakarta Light Rail Transit (LRT) as the case study. Section 2 will discuss the literature study of public-private partnerships and its implementation in the railway projects. Section 3 elaborates transportation in Jakarta and the case study in detail. Section 4 presents the research methodology. Section 5 shows the result and discussion. Last, Section 6 will provide a conclusion and draw some recommendations for public policy and practical implications.

\section{Literature Study}

\subsection{Public-Private Partnership}

Public-private partnership (PPP) has been used in the past three decades to deal with the government's lack of funding to build or maintain infrastructure. Despite a consensus related to the definition of PPP is still being debate today, many would agree that PPP is a long term contract between the government and private entity to plan, develop, fund, and operate public infrastructure by the business entity [10-12]. PPP offers a triple win scenario by accommodating government intention to build infrastructure for the citizen, private interest for investment, and public interest in accessing infrastructure and economic activities [13-15].

Private involvement in facilities and public services procurement is gaining high interest both in developed and emerging countries [16,17]. PPP is believed to be one of the innovative approaches that accommodates the government's limited budget through competitive investment and project efficiency proposed by the private sector. This cooperation also aims for a higher purpose in the longer-term of a mutual relationship between the public and private domain. In order to gain maximum benefits, PPP has four characteristics that should be taken into account prior to the initial agreement, including long term contracts, project life cycle consideration, private innovation, and acceptable benefits gained by the project for both parties [18,19]. These characteristics aim to increase effectiveness and efficiency in its implementation, improve the quality of public products and services, through sharing scenarios in terms of capital, risk, science, and human resources [20-22].

PPP adoption has grown popular over the years due to various reasons. Some of them expected the scheme might improve operational efficiency and improve market competition. While some others aim to deliver new and proven technologies for the domestic market and create employment 
opportunities $[23,24]$. In Southeast Asian countries such as Malaysia, Thailand, and the Philippines, PPP is expected to provide services previously unavailable and reduce monopoly and corruption through transparent procurement mechanisms [25-27].

\subsection{Public-Private Partnership in Railway Projects}

The public-private partnership has been used in many sectors such as construction, roads, energy, and other infrastructure projects to cope with the limited funds of the public sector. This scheme is also adopted in railway projects worldwide to release state budgets through a cost-sharing scenario from the private sector. Some countries, such as in the western part of Europe and Japan, heavily depend on a market based on private investment $[28,29]$. While in some others, mainly from developing countries such as Indonesia, the railway is part of public interest, thus should be managed by the government or representation of the state [30,31].

A partnership between public and private has been adopted in various types of railways worldwide including high-speed trains, metro, LRT, and tramways [3,32]. LRT and tramways are one form of urban transit with dedicated right-of-way mobility. Unlike tramways which mostly operate on the ground, LRT may operate both on the ground or elevated, depending on land availability, land use, and geographical areas. LRT and tramways propose lower construction costs compared to other types of railways in consequence to lower speed and limited numbers in carrying passengers compared to the heavy rail or metro system.

Some cities are implementing tramways for their urban commuting, such as those located in Turkey [32], because of the lack of funding from the central government and being located in medium-sized cities. Tramways are not suitable as a means of transportation in a larger area for service due to a huge population and limited land for acquisition. Light rail, particularly those with an elevated track, provides a competitive investment cost, medium speed of rolling stock, and large number of passengers compared with the metro service. Several countries have adopted LRT into their urban transportation with a range of investment costs. A comparison of LRT projects worlwide can be seen in Table 1.

Table 1. Comparison of several LRT projects.

\begin{tabular}{cccccc}
\hline LRT Project & Location & Operation & Length $\mathbf{( k m )}$ & Type of Track & US\$/km \\
\hline LRT Calgary & Canada & 2026 & 20 & At grade & $155,815,602.84$ \\
LRT Dubai & UAE & 2009 & 76 & Elevated, At grade & $72,765,957.45$ \\
LRT Manila Line 7 & Philippines & 2019 & 23 & Elevated & $64,042,553.19$ \\
LRT Kelana Jaya & Malaysia & 2016 & 34.7 & Elevated, At grade & $57,943,262.41$ \\
LRT Lahore & Pakistan & 2018 & 27.1 & Elevated & $56,524,822.70$ \\
\hline
\end{tabular}

Source: [33].

Despite the differences of management among nations for railway services, the intention to use the PPP scheme came from various reasons, such as being a huge investment that should be allocated by the government, the challenge from other sectors such as road and air transport, poor services provided by current operators, and lack of competition in the market. Some nations, such as Japan, have restructured their railway services by delegating seven for-profit companies to manage the domestic railway market based on geographical area for operation. Other nations, such as the UK, Netherlands, Spain, and many others, conducted regulatory reform to attract private participation through collaboration, standardization, and incentives.

Private involvement in railway projects depends on interest in infrastructure investment (e.g., track, station, stabling yard) or services with or without having rolling stock [9,34]. Some countries, mainly in western Europe, show significant results adopting such a scheme, but other nations require adjustments of PPP to be successfully implemented. Most public projects need a huge investment but generate a low rate of return, particularly projects with a high dependency on farebox as the source of revenue. Little evidence shows railway operators experience a profitable project when non-farebox 
revenue is not maximized. One of the railway operators in Japan has successfully made a profit from railway service due to its capability to generate more than $30 \%$ of income from non-farebox through transit-oriented development, land management and leasing, retail, commercial, and many other sources of revenue [30].

Models for PPP in railways have several combinations based on the project life cycle, type of contract, or feasibility level. The life cycle cost analysis uses a period service of infrastructure which does not exceed 100 years. Based on the literature study shown in Table 2, most of the operation ranges from 30 to 50 years.

Table 2. Comparison of LCC in several projects.

\begin{tabular}{cccc}
\hline Location & Type & Service Life & Source \\
\hline Portugal & High-Speed Rail & 35 years & {$[35]$} \\
Turkey & High-Speed Rail & 35 years & {$[36]$} \\
Turkey & Conventional & 32 years & {$[36]$} \\
Japan & Conventional, High-Speed Train & $30-50$ years & {$[37]$} \\
India & Conventional & 30 years & {$[38]$} \\
France & Conventional, High-Speed Train & 50 years & {$[39]$} \\
\hline
\end{tabular}

Some countries, such as the UK and Netherlands, where the infrastructure manager (IM) exists to manage the infrastructure, private parties are responsible only for the train operation [40]. While in other countries, the private parties only are given the responsibility to provide infrastructure and maintain it in a certain period. However, Indonesia has a unique railway market where state-owned enterprise in the railway sector has a dual role as operator and infrastructure manager to maintain infrastructure and railway expansion. This integrated concession may increase the cost of infrastructure and reduce market competition for better service. Therefore, unbundling the project based on the project life cycle and railway components can be used as one of the most suitable concepts of PPP schemes during the transitional stage from a vertically integrated concept to a fully vertical separation.

\section{Transportation in Jakarta}

Jakarta, as the capital city of Indonesia, is the largest city in the country. Jakarta has an area of $661.52 \mathrm{~km}^{2}$ with a population of 10,374,235 inhabitants in 2017. The Jakarta metropolitan area (Jabodetabek), which in total has nearly 30 million people, is the largest metropolitan area in Southeast Asia or second in the world. Based on the [41] report, Jakarta's population has experienced a steady increase and the population is projected to reach its highest peak in 2040, reaching 11.28 million. In terms of the economic landscape, Jakarta contributes approximately $17 \%$ national gross domestic product (GDP), which ranked first above other provinces in the nation. Considering the growing population and economic development, this city requires integrated transportation through buses, urban transit, and non-motorized transport.

Prior to the operation of mass rapid transit (MRT) of Jakarta in the first quarter of 2019, the citizens of Greater Jakarta depended on regular buses, heavy rail, bus rapid transit (BRT), and paratransit. BRT and heavy rail span more than $230 \mathrm{~km}$ and serve between 721,000 and 1 million passengers per day, respectively. Despite the available options for traveling, citizen tends to use private vehicles rather than public transportation due to safety reasons, a disintegrated network, and bad services. The MRT and light rail transit (LRT) construction aims to provide an alternative mode of transportation, and in the longer-term, reduce traffic congestion caused by the increased use of private vehicles. The railway also ensures a safer journey for users to reach their destination by providing a dedicated track and route $[42,43]$.

Greater Jakarta LRT is a mass transit system that connects the capital city and adjacent city/regency of West Java and Banten provinces. The transit will span about $44.3 \mathrm{~km}$ in the first phase and $83.6 \mathrm{~km}$ when completed. Currently, three lines with 16 stations are under construction and expected to begin 
operation in 2021. The investment cost for the first phase of the LRT approximately reaches US\$ 2.11 billion or equal to US $\$ 47.73$ million $/ \mathrm{km}$. The cost of investment supported by the government, while the operation and maintenance remain on hold, whether using the tendering process or adopting the delegation process to a state-owned enterprise of transportation (see Figure 1).

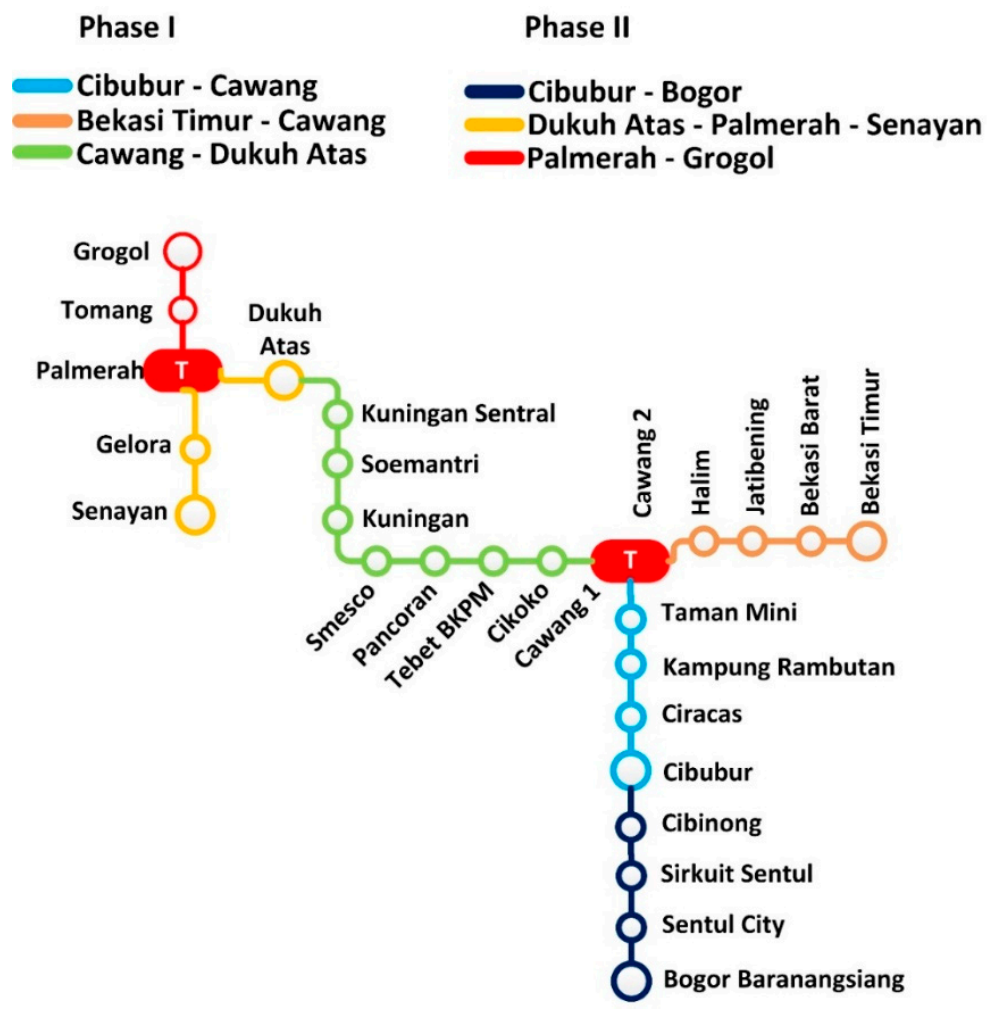

Figure 1. Greater Jakarta LRT route plan.

\section{Research Methodology}

In conducting the project evaluation, this research adopts a two-stage approach. Firstly, a life cycle cost is performed. The total cost of the railway project over its project life cycle involves the cost of three major components, including investment cost, which represent the costs of demolishing fee, civil works, stabling yards, signaling, to consulting fees. On the other hand, the usage cost involves the operation and maintenance costs from operating the railway. Last, the component of income obtained from farebox and non-farebox revenue. This research adopts 40 years of operation for the LCC analysis.

The operation and maintenance cost experience an increased value over time due to inflation. This study evaluates the inflation value based on transportation and the general sector extracted from the public domain (see Figure 2). The average inflation rate is $3.23 \%$ and $4.51 \%$, respectively. Another consideration in OM activities is overhaul activity, which will be conducted every 10 years. The number of train cars will be summed into 37 units in 2027, which then becomes 56 units in 2042 due to exponential growth from passenger forecasting. 


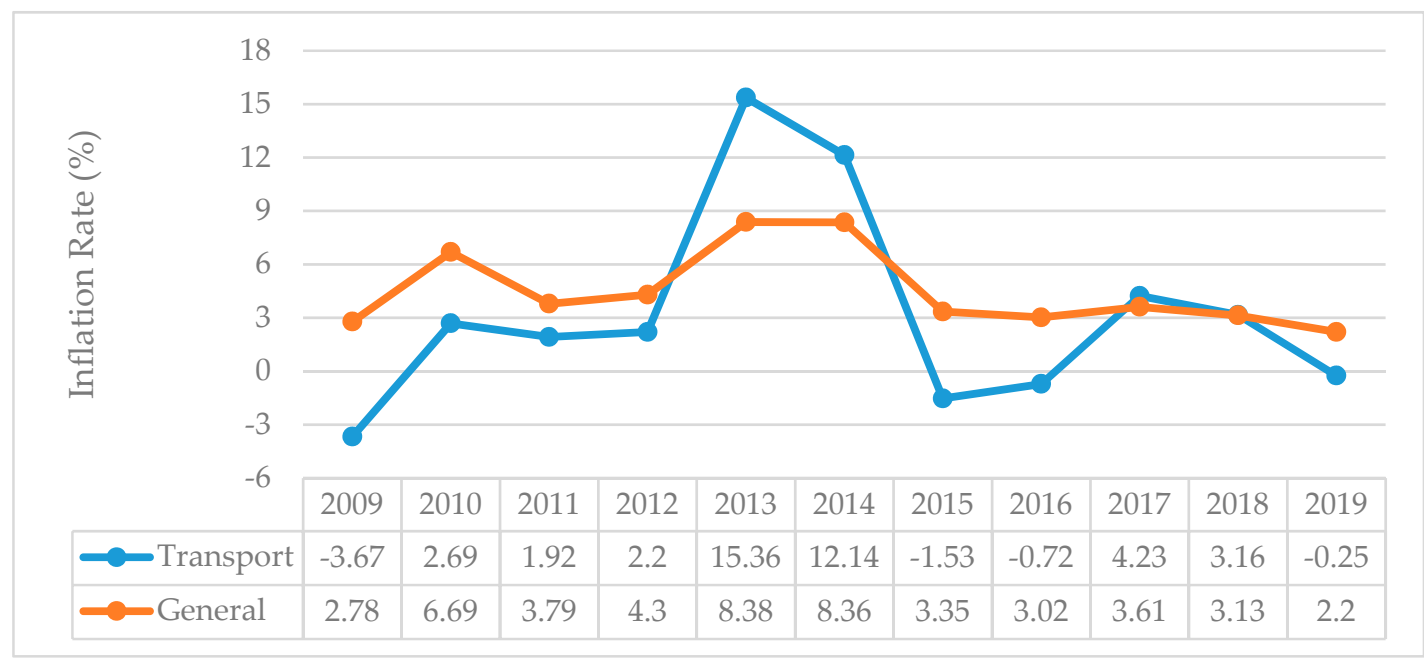

Figure 2. Inflation rate of transportation and the general sector in Indonesia. Source: [44].

Unpublished reports from the Ministry of Transportation of the Republic of Indonesia estimate that Greater Jakarta LRT will reach 210,000 passengers per day. However, considering the Manila LRT that only achieved $40 \%$ of its targeted revenue in the first year on the operational stage, this analysis uses passengers' demand with $33 \%$ of the current demand or equal to 69,300 passengers per day.

In the second stage, three scenarios of the PPP scheme on the operational stage were carried out. It considers the division of responsibility between the government and private party on stabling yard construction, rolling stock procurement, and without investment. The scheme considers financial requirements that would interest an investor to be involved in a transportation project shown by positive net present value (NPV) and significant internal rate of return (IRR). The NPV considers the amount and estimated future cash flows discounted at the current time. The NPV follows the equation: $N P V=\sum_{t=1}^{T} \frac{C_{t}}{(1+r)^{t}}-C_{o}$, where, NPV $=$ net present value, $C_{t}=$ net cash inflow during the period $\mathrm{t}, \mathrm{C}_{\mathrm{o}}=$ total initial investment, $r=$ discount rate (\%). The result from NPV should be no less than zero, so that the government may justify that the project follows public interest. On the other hand, the private sector will acknowledge a higher number of NPV to be involved in the project. The internal rate of return is the minimum discount rate that aims to identify capital investments or future projects that reach a targeted acceptable return. The IRR formula is calculated by the sum up to the present value of future cash flow less than the initial investment to zero. The scenario will be selected based on the combination of NPV, IRR, and government support.

\section{Result and Analysis}

\subsection{Investment Cost}

Investment cost in this project has been handled entirely by the government of Indonesia as state support. The state divides the cost into three major components; construction cost, project management cost, and loan interest. Civil works contribute as the highest cost, among others, with $45.47 \%$, followed by power supply with $12.84 \%$. Other components contribute less than $10 \%$ to the total investment cost. The detail of investment cost can be seen in Table 3 . 
Table 3. Component of investment cost in the case study.

\begin{tabular}{cccc}
\hline Category & Components & Cost (US\$) & Percentage \\
\hline \multirow{4}{*}{ Construction Cost } & Demolishing fee & $5,080,000$ & $0.41 \%$ \\
& Civil work & $557,870,000$ & $45.47 \%$ \\
& Communication & $38,730,000$ & $3.16 \%$ \\
& Signalling & $100,670,000$ & $8.21 \%$ \\
& Power supply & $157,550,000$ & $12.84 \%$ \\
& FAS \& BAS & $10,570,000$ & $0.86 \%$ \\
PM Cost & AFC & $18,490,000$ & $1.51 \%$ \\
& Equipment of RS and in the stabling yard & $20,870,000$ & $1.70 \%$ \\
\hline \multirow{2}{*}{ Others } & Value added tax & $103,580,000$ & $8.44 \%$ \\
& Project management and consulting fee & $95,190,000$ & $7.76 \%$ \\
& Contigency & $45,490,000$ & $3.71 \%$ \\
& Loan interest & $72,710,000$ & $5.93 \%$ \\
& SUB-TOTAL & $1,226,800,000$ & $100 \%$ \\
\hline \multirow{2}{*}{ Overhaul } & Rolling Stock procurement & $126,000,000$ & $85.79 \%$ \\
& Stabling yard & $20,870,000$ & $14.21 \%$ \\
& SUB-TOTAL & $148,870,000$ & $100 \%$ \\
\hline & Overhaul in 10th years operation & $1,628,000$ & $39.78 \%$ \\
& Overhaul in 15th years operation & $2,464,000$ & $60.22 \%$ \\
& SUB-TOTAL & $4,092,000$ & $100 \%$ \\
\hline
\end{tabular}

\subsection{Operation and Maintenance Cost}

Operation and maintenance cost during the project life cycle categorized into three major components including infrastructure, rolling stock, and overhead, which adopt regulation from the Ministry of Transportation, Republic of Indonesia. O\&M of rolling stock will consist of operating staff, maintenance staff, and maintenance components. On the other hand, O\&M of infrastructure will be divided into maintenance staff and maintenance components. The operation and maintenance are divided into three stages; the first year of operation, ten years of operation, and fifteen years of operation considering passenger forecasting which affects the total number of rolling stock.

Staffing to operate the rolling stock is evaluated based on the benchmarking process [45] and a site visit to existing railway service in the capital city of Indonesia. The total number of staff considers the number of rolling stock, stations, command center, and local minimum wage. On the other hand, staffing for infrastructure maintenance only considers the infrastructure itself and the local minimum wage. Regarding rolling stock components for maintenance, some reports use the number of vehicles [45], while other reports use traffic flow expressed by vehicle. $\mathrm{km}$. This research adopts traffic flow which proposes more detail forecasting for the project. This type of calculation uses three periods of daily operation; peak hour, day hour, and evening. LRT operational time is planned for $18 \mathrm{~h}$ from 05.00-23.00. On weekdays, the LRT operates at peak hour lasting for $8 \mathrm{~h}$, day hour lasting for $6 \mathrm{~h}$, and evening lasting for $4 \mathrm{~h}$. On weekends, the LRT operates on a day and hour basis, lasting for $14 \mathrm{~h}$ and evening hours lasting for $4 \mathrm{~h}$. This scheme provides a different number of rolling stock on each period, thus potentially reducing the overall cost of operation and maintenance.

Staff for operation and maintenance of infrastructure consist of those who deal with track, switches, stations, power, and stabling yards components. The personnel's work is based on the maintenance period and components deterioration. Overall, the infrastructure component consumes the largest cost in the operation and maintenance stage with $47.87 \%$ annually, followed by rolling stock component with $26.89 \%$, and operation staff with $12.14 \%$. The operator's cost during the operation and maintenance stage may consist of office, travel, insurance, and personnel education. The cost estimated is about $20 \%$ of the annual cost of O\&M. The detail component of operation and maintenance cost can be seen in Table 4. 
Table 4. Component of annual cost in operation and maintenance stage.

\begin{tabular}{ccc}
\hline Components & Cost (US\$) & Percentage \\
\hline Operation Staff & $2,742,349.57$ & 12.14 \\
Maintenance Staff & $313,253.77$ & 1.39 \\
Rolling stock component & $6,075,993.35$ & 26.89 \\
Maintenance Staff & $482,245.88$ & 2.13 \\
Infrastructure component & $10,815,452.56$ & 47.87 \\
Overheads & $4,085,859.03$ & 9.57 \\
TOTAL & $22,592,385.64$ & $100 \%$ \\
\hline
\end{tabular}

\subsection{Revenue}

The railway project obtains income from two sources, including farebox and non-farebox. The ticket price was set to US\$1.07, with 33\% of the occupancy rate from initial annual passengers set by the government. On the other hand, non-farebox income was set to $10 \%$ of the total farebox of the LRT project. Non-farebox may be generated through advertisement, retail, and commercial areas both in and outside the stations.

\subsection{Public-Private Partnership Scheme}

\subsubsection{First Scenario}

In the first scenario, the investment cost, particularly construction and project management costs, were handled by the government. The government is also responsible for rolling stock availability upon the operational phase. On the other hand, the private entity is responsible for stabling yard construction and its maintenance and operation, as well as rolling stock operation and maintenance. The operation and maintenance cost during the project life cycle increases every year following inflation of the transportation sector, and overhaul every 10 -year period. With this scenario, the private entity may gain a prospective rate of return as $10.80 \%$ for 40 years of operation. However, this scenario places a huge sunk cost from the public sector as US\$1,352,800,000 or $98.48 \%$ from the investment cost of the project.

\subsubsection{Second Scenario}

In the second scenario, the private entity is only responsible for maintaining infrastructure and renewals. Investment cost, including rolling stock procurement and stabling yard, will be supported by the government. Similar treatment of the financial estimation as the first scenario was conducted. The result shows positive net present value (NPV) and an internal rate of return (IRR) as $8.58 \%$.

\subsubsection{Third Scenario}

In the third scenario, construction and project management costs were also handled by the government along with stabling yard construction. On the other hand, the private entity is responsible for procuring rolling stock and handling its maintenance. They are also responsible for maintaining infrastructure and renewals. The findings argue that this scheme offers negative results, both in terms of net present value (NPV) and internal rate of return (IRR). The comparison of the scenario can be seen in Table 5. 
Table 5. Comparison of three scenarios in PPP.

\begin{tabular}{cccc}
\hline Cost Component & First Scenario & Second Scenario & Third Scenario \\
\hline Passenger Demand (33\%) & $25,294,500$ & $25,294,500$ & $25,294,500$ \\
Ticket Price (US\$) & 1.07 & 1.07 & 1.07 \\
IRR (\%) & 10.80 & 8.58 & N/A \\
NPV (million US\$) & 1.33 & 25.58 & -120.80 \\
Government Support (\%) & 98.48 & 100 & 90.83 \\
\hline
\end{tabular}

\subsection{Sensitivity Analysis}

In conducting financial analysis, there are numbers of uncertainty which may affect the accuracy of the results consisting of a tariff, passenger demand, investment cost, as well as operation and maintenance cost. A sensitivity analysis is normally adopted to evaluate uncertainty components to the internal rate of return of the project. This research assesses two components, including passenger demand and ticket price, among others, due to its ability in affecting investor's interest involved in the project.

In terms of passenger demand, the sensitivity analysis considers five scales from 30 to $40 \%$ and is applied to three scenarios. Overall, scenario three generates negative NPV from all five scales, while the two other scenarios provide positive NPV when passenger demand starts from $33 \%$ and above. Scenario 2 produces the highest NPV from five scales of analysis followed by scenario 1 and scenario 3. From scenario one and scenario two, which proposed positive NPV, an increase of $2-3 \%$ of passenger demand may produce US\$25.71 million to US\$ 42.42 million of NPV. Passenger demand of $30 \%$ generates negative NPV for all scenarios, therefore the operator needs to ensure the revenue meets $33 \%$ of passenger demand to prevent financial losses. The sensitivity analysis that takes into account passenger demand can be seen in Figure 3.

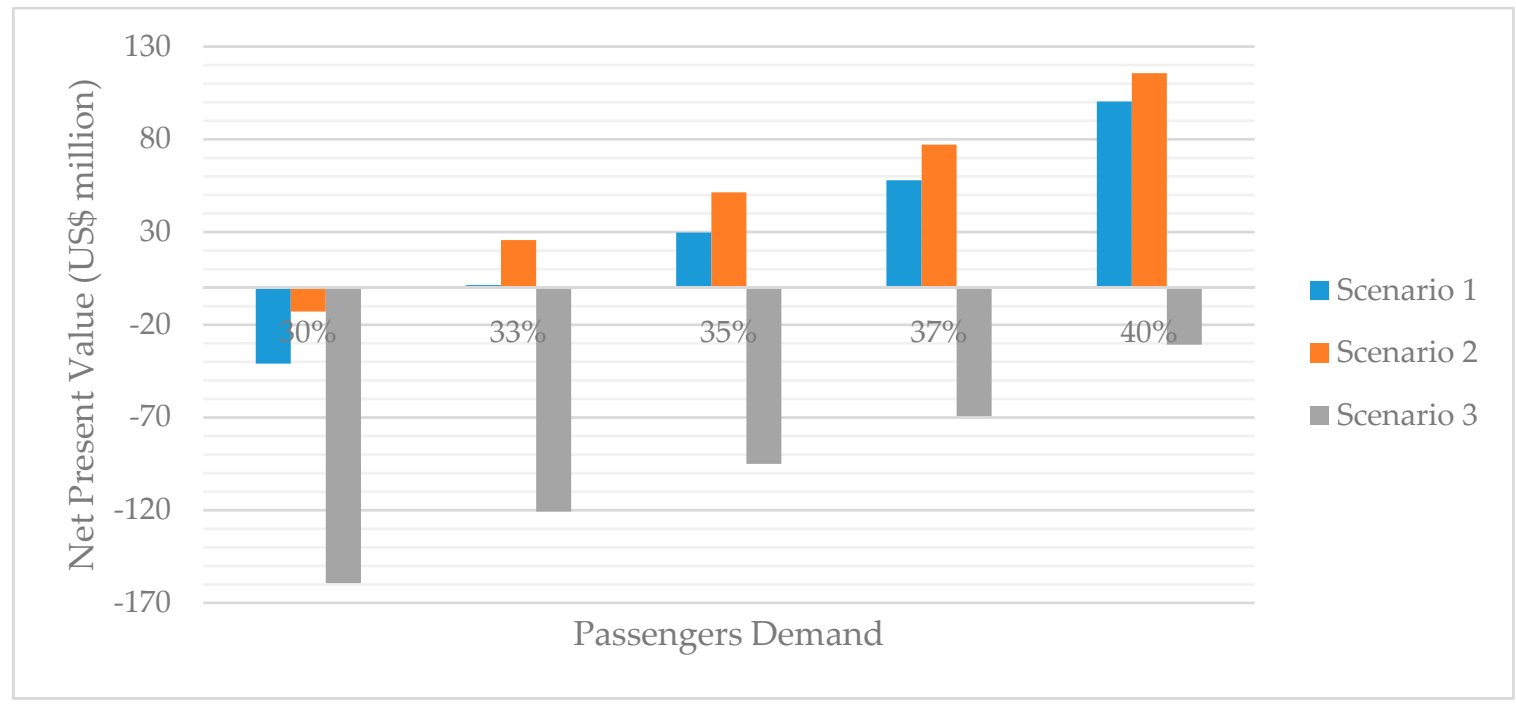

Figure 3. Sensitivity analysis from passengers demand.

On the other hand, five scales of ticket price for the sensitivity analysis range from 1.07 to 1.34. Scenario 3 shows a progressive NPV from each increased of ticket price. Scenario 2 provides the highest NPV among other scenarios. Unlike the passenger demand component where all scenarios produce negative NPV, only scenario 3 proposes negative NPV on the lowest ticket price. Based on these scenarios, rising the ticket price about 6-7 cents may contribute to an increased NPV from US\$ 24.89 million to US\$30.18 million. The result of the sensitivity analysis based on ticket price can be seen in Figure 4. 


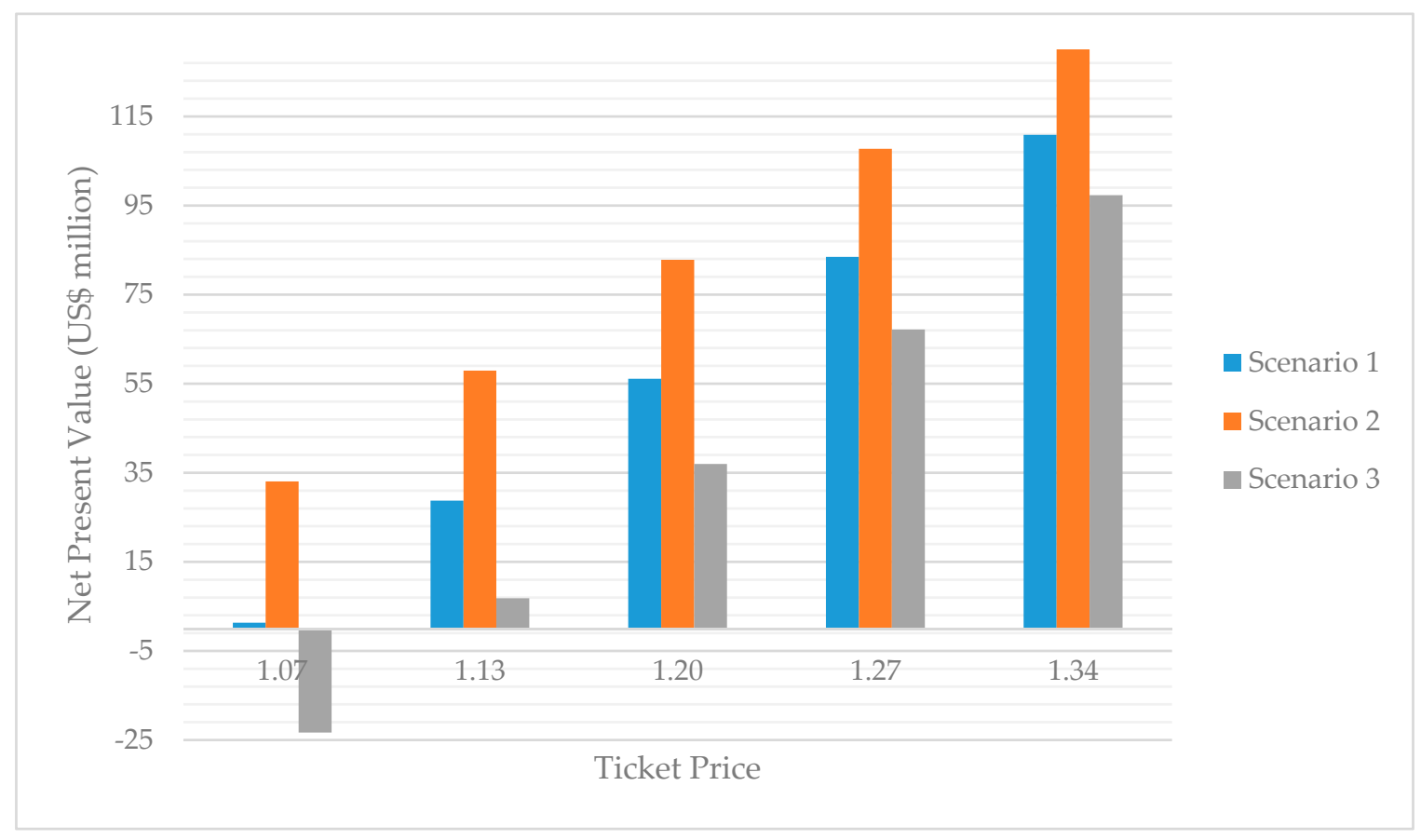

Figure 4. Sensitivity analysis of the ticket price.

\subsection{Discussion}

The results from the sensitivity analysis show a different impact on the project's rate of return. Higher projection of demand and increase of ticket price contributed to the higher NPV, which may attract investor interest due to the optimum benefit they might gain from this project. Accuracy of determining the demand then becomes significant, which should be prioritized during the initial and planning stages. Inaccurate planning regarding passenger demand has affected most of the railway projects, such as the Metro Manila LRT line 1 which only reached $52.4 \%$ from total forecasted passengers for the first two years of operation. In contrast, the tariff in Metro Manila LRT line 1 is rather competitive compared to other countries ranging from 6-12 peso or less than US\$ 1/trip [46].

Considering such conditions, this research proposed $33 \%$ of passenger demand from initial planning to decrease potential losses in the initial years of operation. However, the pessimist scenario of demand and tariff will also lead to a huge income gained by the operator when actual revenue beyond this paper is suggested. Therefore, a comprehensive contract which involves the option of re-negotiation for decreasing the concession period or tariff reduction. Involving stakeholders who have the ability to deal with international and domestic law to provide input to develop such a contract benefitting both parties is crucial to the project realization.

Based on the research findings in the sensitivity analysis section, the main challenge in the PPP scheme for operation and maintenance is placed on the government side. While the result shows private entities will gain attractive income based on positive NPV and positive rate of return, the government, through delegated ministry, should consider their fiscal capacity for investment cost and operation support. Considering the public perspective, scenario 1 might be selected due to lower government support of subsidy. This scenario also offers positive NPV and competitive rates of return which are relatively attractive from the private entity. Thus, this scenario is expected to reduce state subsidy without compromising the private sector interest in gaining profit from an infrastructure project while at the same time providing railway services for user mobility and connectivity.

\section{Conclusions}

The public-private partnership has been extensively used by many countries worldwide to assist decision making in releasing state deficiencies funding infrastructure projects. Despite many attempts 
to develop a framework of PPP particularly in railway projects, there is limited evidence dealing with the concept for the operation and maintenance phase. This research aims to discuss the possibilities in adopting the PPP scheme in railway project development by taking into account the Greater Jakarta Light Rail Transit (LRT) as the case study. This project is a strategic national project to connect suburban citizens into the city center through reliable means of public transportation in terms of time travel and cost-efficiency. The case is a good example of how to develop a partnership scheme in later stages of the project life cycle which can be adopted to other sectors or countries experiencing similar challenges.

The scenario proposed by this research provides a possible way to solve the government's lack of funding during the operation stage for megaproject infrastructure through the public-private partnership scheme. The scenario was based on financial simulation and division of responsibility between each party of the public and private sector. A set of alternatives was provided for the decision-making process and the optimal rate of return was proposed. The selection of scenarios was mainly determined by the confidence level from the public side regarding passenger demand to fulfill LRT occupancy rates. As a result, thorough transportation planning and supported mitigation strategies were required to cope with future challenges of demands and tariff. This research also suggests the expansion of the role of both government and private sides, thus it might require changes in national policy and regulation.

Although it would be unwise to claim the scenario completely solved practical problems in railway project development, the recommendation scenario in this study elaborates knowledge and encourages more collaboration between the public and private entity. Additionally, this research provides alternatives choices that can be used by related stakeholders in decision-making modeling in the future. As it is difficult to validate the proposed concept due to dynamic changes in the real-world and numerous uncertainties occurring in the project, the study might be used as initial steps to model more comprehensive planning in the operation and maintenance stage, particularly in railway projects. This study was not involved in risk-sharing between parties and policy evaluation for scenario mapping. Future direction of the research may include but not be limited to risk-sharing in public-private partnership (PPP), policy implication from PPP, institutional scheme of railway project using PPP, vertical separation of railway in the PPP context.

Author Contributions: Conceptualization, H.Z.R. and P.M.; data curation, A.A.; writing-review \& editing, P.M.

Funding: This research received no external funding.

Acknowledgments: This research is supported by a grant from Ministry of Research and Higher Education, Republic of Indonesia and supplied data from the Directorate of Investment-Directorate General of Railways, Ministry of Transportation, Republic of Indonesia.

Conflicts of Interest: The authors declare no conflict of interest.

\section{References}

1. Panayiotou, A.; Medda, F. Attracting private sector participation in infrastructure investment: The UK case. Public Money Manag. 2014, 34, 425-431. [CrossRef]

2. Gnap, J.; Varjan, P.; Durana, P.; Kostrzewski, M. Research on Relationship Between Freight Transport and Transport Infrastructure in Selected European Countries. Transp. Probl. Int. Sci. J. 2019, 14, 63-74.

3. Chou, J.-S.; Tserng, H.P.; Lin, C.; Yeh, C.-P. Critical factors and risk allocation for PPP policy: Comparison between HSR and general infrastructure projects. Transp. Policy 2012, 22, 36-48. [CrossRef]

4. Olatunji, S.O.; Olawumi, T.O.; Ogunsemi, D.R. Demystifying issues regarding public private partnerships (PPP). J. Econ. Sustain. Dev. 2016, 7, 1-22.

5. Ministry of Finance Singapore. Public Private Partnership Version 2; Ministry of Finance: Singapore, 2012.

6. Zen, F. Public Private Partnership in South East Asia; Asian Development Bank: Mandaluyong, Philippines, 2018.

7. Utami, S.P.S. Hingga 2018, sudah 57 proyek infrastruktur gunakan skema KPBU. Kontan, 15 January 2019.

8. Primadhyta, S. PII Hadapi Dua Kendala Garap Infrastruktur dengan Skema KPBU. CNN Indonesia, 22 December 2016. 
9. Gangwar, R.; Raghuram, G. Framework for structuring public private partnerships in railways. Case Stud. Transp. Policy 2015, 3, 295-303. [CrossRef]

10. Garvin, M.J. Enabling development of the transportation public-private partnership market in the United States. J. Constr. Eng. Manag. 2009, 136, 402-411. [CrossRef]

11. Ramsey, D.W.; El Asmar, M. Cost and Schedule Performance Benchmarks of US Transportation Public-Private Partnership Projects: Preliminary Results. Transp. Res. Rec. 2015, 2504, 58-65. [CrossRef]

12. Medda, F.R.; Carbonaro, G.; Davis, S.L. Public private partnerships in transportation: Some insights from the European experience. IATSS Res. 2013, 36, 83-87. [CrossRef]

13. Ortiz, I.N.; Buxbaum, J.N. Protecting the public interest in long-term concession agreements for transportation infrastructure. Public Work Manag. Policy 2008, 13, 126-137. [CrossRef]

14. Oliveira, M.; Ribeiro, J.; Macário, R. Are we planning investments to fail? Consequences of traffic forecast effects on PPP contracts: Portuguese and Brazilian cases. Res. Transp. Econ. 2016, 59, 167-174. [CrossRef]

15. Berawi, M.A.; Suwartha, N.; Kurnia, K.; Miraj, P.; Berawi, A.R.B. Forecasting the land value around commuter rail stations using Hedonic price modeling. Int. J. Technol. 2018, 9, 1329-1337. [CrossRef]

16. Ameyaw, E.E.; Chan, A.P.; Owusu-Manu, D.-G. A survey of critical success factors for attracting private sector participation in water supply projects in developing countries. J. Facil. Manag. 2017, 15, 35-61. [CrossRef]

17. Repolho, H.M.; Antunes, A.P.; Church, R.L. PPP motorway venture-An optimization model to locate interchanges with social welfare and private profit objectives. Transp. A Transp. Sci. 2016, 12, 832-852. [CrossRef]

18. Weber, B.; Staub-Bisang, M.; Alfen, H.W. Infrastructure as an Asset Class: Investment Strategy, Sustainability, Project Finance and PPP, 2nd ed.; John Wiley \& Sons: Hoboken, NJ, USA, 2016.

19. Ismail, S. Critical success factors of public private partnership (PPP) implementation in Malaysia. Asia Pac. J. Bus. Adm. 2013, 5, 6-19. [CrossRef]

20. Bult-Spiering, M.; Dewulf, G. Strategic Issues in Public-Private Partnerships: An International Perspective; John Wiley \& Sons: Hoboken, NJ, USA, 2008.

21. Liu, J.; Love, P.E.; Smith, J.; Regan, M.; Davis, P.R. Life cycle critical success factors for public-private partnership infrastructure projects. J. Manag. Eng. 2014, 31, 04014073. [CrossRef]

22. Jooste, S.F.; Levitt, R.; Scott, D. Beyond 'one size fits all': How local conditions shape PPP-enabling field development. Eng. Proj. Organ. J. 2011, 1, 11-25. [CrossRef]

23. Chan, A.P.; Yeung, J.F.; Yu, C.C.; Wang, S.Q.; Ke, Y. Empirical study of risk assessment and allocation of public-private partnership projects in China. J. Manag. Eng. 2010, 27, 136-148. [CrossRef]

24. Soomro, M.A.; Zhang, X. Roles of private-sector partners in transportation public-private partnership failures. J. Manag. Eng. 2013, 31, 04014056. [CrossRef]

25. Mohamad, R.; Ismail, S.; Mohd, J. Performance objectives of public private partnership implementation in Malaysia: Perception of key players. J. Asia Bus. Stud. 2018, 12, 17-30. [CrossRef]

26. Koppenjan, J.F.; Enserink, B. Public-private partnerships in urban infrastructures: Reconciling private sector participation and sustainability. Public Adm. Rev. 2009, 69, 284-296. [CrossRef]

27. Berawi, M.A.; Nabila, A.; Miraj, P.; Rahman, H.A.; Berawi, A.R.B. Analysis of life cycle cost and public-private partnership in the development of Walini City as technology park. Int. J. Technol. 2018, 9, 1469-1479. [CrossRef]

28. Iossa, E.; Saussier, S. Public private partnerships in Europe for building and managing public infrastructures: An economic perspective. Ann. Public Coop. Econ. 2018, 89, 25-48. [CrossRef]

29. Newman, P.; Davies-Slate, S.; Jones, E. The Entrepreneur Rail Model: Funding urban rail through majority private investment in urban regeneration. Res. Transp. Econ. 2018, 67, 19-28. [CrossRef]

30. Rahman, H.Z.; Berawi, M.A.; Susantono, B.; Miraj, P.; Petroceany, J.S.; Maya, R. Investigation of an operation and maintenance framework in the railway industry: A case study of the makassar-parepare. Int. J. Technol. 2018, 9, 549-557. [CrossRef]

31. Berawi, M.A.; Ibrahim, B.E.; Miraj, P. Developing A Conceptual Design of Transit-Oriented Development To Improve Urban Land Use Planning. J. Des. Built Environ. 2019, 19, 40-48.

32. Alpkokin, P.; Kiremitci, S.T.; Black, J.A.; Cetinavci, S. LRT and street tram policies and implementation in turkish cities. J. Transp. Geogr. 2016, 54, 476-487. [CrossRef]

33. LRT Greater Jakarta. Comparison of Greater Jakarta LRT Costs with 5 Other Countries; Kompas: Jakarta, Indonesia, 2019. 
34. Berawi, M.A.; Miraj, P.; Berawi, A.R.B.; Akbar, F. A benchmark study for Indonesia's high speed train considering technology selection. Adv. Sci. Lett. 2017, 23, 6343-6346. [CrossRef]

35. Jones, H.L.; Moura, F.; Domingos, T. Transportation Infrastructure Project Evaluation: Transforming CBA to Include a Life Cycle Perspective. In Handbook of Sustainability Science and Research; Springer: Cham, Switzerland, 2018; pp. 745-771.

36. Banar, M.; Özdemir, A. An evaluation of railway passenger transport in Turkey using life cycle assessment and life cycle cost methods. Transp. Res. Part D Transp. Environ. 2015, 41, 88-105. [CrossRef]

37. Morisugi, H. Evaluation methodologies of transportation projects in Japan. Transp. Policy 2000, 7, 35-40. [CrossRef]

38. Shinde, A.M.; Dikshit, A.K.; Singh, R.K.; Campana, P.E. Life cycle analysis based comprehensive environmental performance evaluation of Mumbai Suburban Railway, India. J. Clean. Prod. 2018, 188, 989-1003. [CrossRef]

39. Bosquet, R.; Jullien, A.; Vandanjon, P.O.; Dauvergne, M.; Sanchez, F. Eco-design model of a railway: A method for comparing the energy consumption of two project variants. Transp. Res. Part D Transp. Environ. 2014, 33, 111-124. [CrossRef]

40. Wellings, R. The privatisation of the UK railway industry: An experiment in railway structure. Econ. Aff. 2014, 34, 255-266. [CrossRef]

41. Statistics Indonesia. The Total Population of DKI Jakarta According to the 2015-2045 Projection; Statistics Indonesia: Jakarta, Indonesia, 2018.

42. Chudzikiewicz, A.; Bogacz, R.; Kostrzewski, M.; Konowrocki, R. Condition monitoring of railway track systems by using acceleration signals on wheelset axle-boxes. Transport 2018, 33, 555-566. [CrossRef]

43. Czwajda, L.; Kosacka-Olejnik, M.; Kudelska, I.; Kostrzewski, M.; Sethanan, K.; Pitakaso, R. Application of prediction markets phenomenon as decision support instrument in vehicle recycling sector. LogForum 2019, 15, 265-278. [CrossRef]

44. Statistics Indonesia. Indonesia's Inflation Based on Commodity During 2006-2019 Period; Statistics Indonesia: Jakarta, Indonesia, 2019.

45. Halcrow. Cost Estimate Study; Halcrow: London, UK, 2005.

46. Japan International Cooperation Agency. Metro Manila LRT Line 1 Capacity Expansion Project; JICA: Tokyo, Japan, 2004.

(C) 2019 by the authors. Licensee MDPI, Basel, Switzerland. This article is an open access article distributed under the terms and conditions of the Creative Commons Attribution (CC BY) license (http://creativecommons.org/licenses/by/4.0/). 